\title{
Molecular control of luteal secretion of progesterone*
}

\author{
Gordon D. Niswender \\ Animal Reproduction and Biotechnology Laboratory, Colorado State University, \\ Fort Collins, CO 80523-1683, USA
}

\begin{abstract}
Cholesterol provided by low- or high-density lipoprotein is the precursor for biosynthesis of progesterone. Once inside the cell, cholesterol can be used for steroidogenesis or esterified with long-chain fatty acids and stored as cholesterol esters in lipid droplets. When it is needed for steroidogenesis, free cholesterol is transported to the mitochondrion via a mechanism that involves cytoskeletal elements and sterol carrier proteins. Cytochrome P450 cholesterol side chain cleavage enzyme complex converts the cholesterol to pregnenolone, which is then converted to progesterone by $3 \beta$-hydroxysteroid dehydrogenase $/ \Delta^{5}, \Delta^{4}$ isomerase in the smooth endoplasmic reticulum. Transport of cholesterol from the cytoplasm to the inner mitochondrial membrane is both the ratelimiting step in progesterone biosynthesis and the step most acutely influenced by second messengers. Steroidogenic acute regulatory protein (StAR) and peripheral-type benzodiazepine receptors (PBR) are involved in this transport. StAR may bind cholesterol in the cytosol and transport it to the mitochondrial membrane where PBR is involved in transport from the outer to the inner mitochondrial membrane. Phosphorylation of StAR by protein kinase A (PKA) stimulates cholesterol transport, whereas phosphorylation by PKC may inhibit this process. Endozepine, the natural ligand for PBR, also appears to be involved in regulation of the rate of cholesterol transport to the inner mitochondrial membrane and to play a role in the stimulatory effects of PKA on steroidogenesis. Increased concentrations of endozepine were detected in large luteal cells, and may explain the increased progesterone secretion from this type of cell. Fluorescence energy transfer procedures indicate that StAR associates with PBR in mitochondrial membranes. A model is presented for the proposed interactions of StAR, PBR and endozepine in the transport of cholesterol from the outer to the inner mitochondrial membrane.
\end{abstract}

The control of progesterone synthesis in the corpus luteum is more complex than is shown in the general pathway for biosynthesis of progesterone in a luteal cell (Fig. 1) because there are at least two morphologically and biochemically distinct steroidogenic types of cell in the corpus luteum of cattle and sheep and most other mammalian species (Niswender and Nett, 1994; Fig. 2). In ewes, small luteal cells are 12-20 $\mu \mathrm{m}$ in diameter, thought to be of follicular thecal cell origin, contain receptors for $\mathrm{LH}$, respond to $\mathrm{LH}$ or cAMP with a 5-15-fold increase in secretion of progesterone, and often contain numerous lipid droplets. Large luteal cells $(>20 \mu \mathrm{m})$ are primarily of granulosal cell origin, secrete high basal concentrations of progesterone, and although $\mathrm{LH}$ receptors are present, do not respond to $\mathrm{LH}$ or cAMP with increased secretion of progesterone. Large cells contain receptors for $\mathrm{PGF}_{2 \alpha}$ and respond to this hormone

Email: niswend@colostate.edu

*This review is based on the Hammond Lecture given at the meeting of the Society for the Study of Fertility in Utrecht in December 2000. with activation of at least two second messenger pathways. Activation of protein kinase $\mathrm{C}$ (PKC) results in decreased secretion of progesterone. Increased concentrations of intracellular free calcium (Wiltbank et al., 1991) resulting from increased binding of $\mathrm{PGF}_{2 \alpha}$ to its receptor appear to induce apoptosis and cell death. Steroidogenic luteal cells also contain a broad array of receptors for additional regulatory hormones and factors that may or may not be cell-type specific.

\section{Chronic regulation of the secretion of progesterone}

It has been known for some time that LH is critical for normal luteal function in domestic animals (Kaltenbach et al., 1968; Denamur et al., 1973; Hansel et al., 1973). Many of the actions of $\mathrm{LH}$ on luteal cells have been elucidated and both acute and long-term effects of LH on luteal steroidogenesis have been demonstrated. Stimulation by $\mathrm{LH}$ is critical for the long-term steroidogenic capability of luteal cells, including maintenance of normal amounts of mRNA encoding $3 \beta$-hydroxysteroid dehydrogenase $/ \Delta^{5}, \Delta^{4}$ isomerase (3ß-HSD), cytochrome P450 side chain cleavage enzyme 


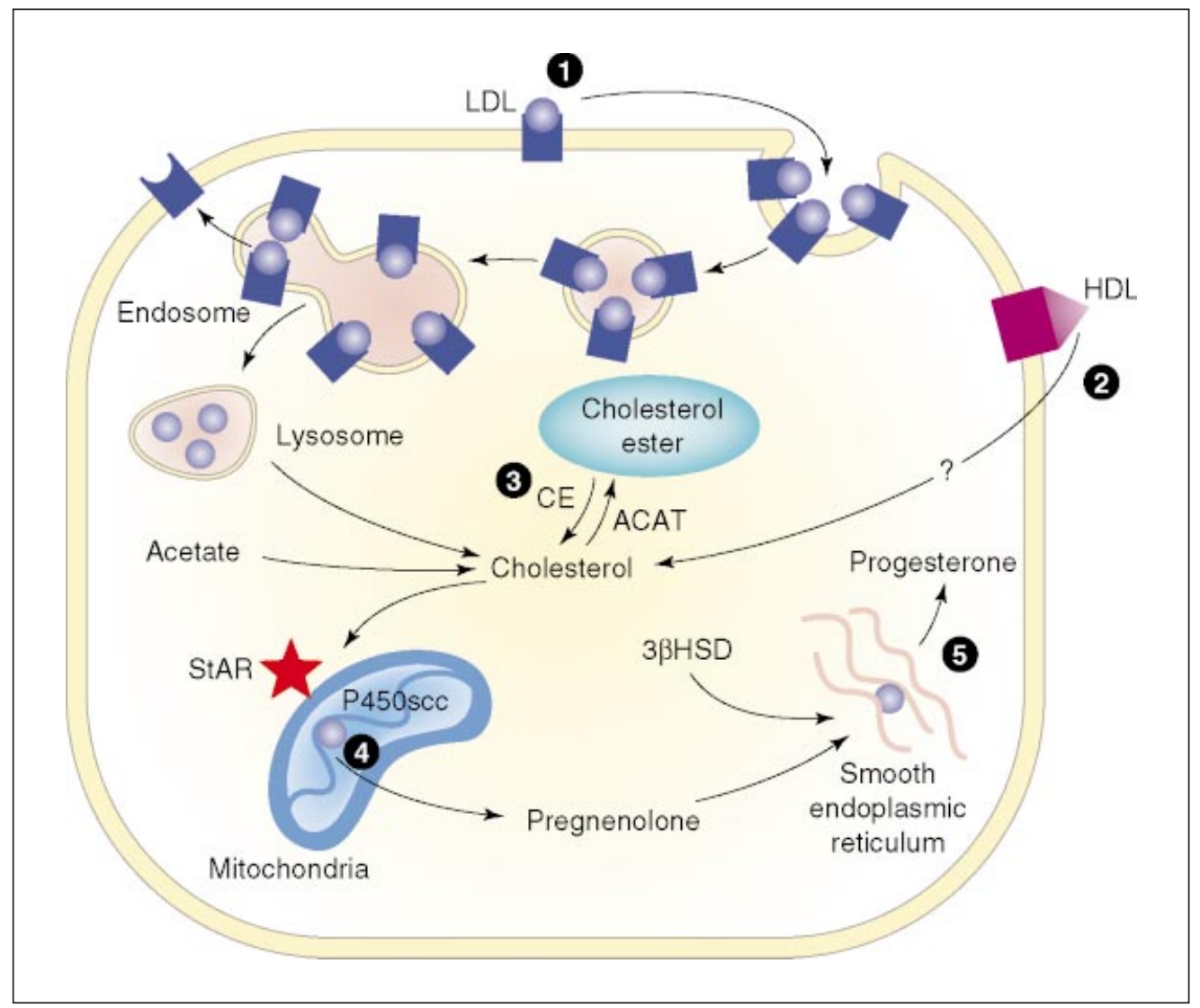

Fig. 1. Pathway for progesterone biosynthesis in a generic luteal cell. Three sources of cholesterol can be used as substrate: (1) low density lipoprotein (LDL); (2) high density lipoprotein (HDL); or (3) hydrolysis of stored cholesterol esters by cholesterol esterase (CE). The free cholesterol is transported to the mitochondria apparently with the involvement of cytoskeletal elements and sterol carrier proteins. Cholesterol is then transported from the outer to the inner mitochondrial membrane, and this process appears to involve steroidogenic acute regulatory protein (StAR), peripheral type benzodiazepine receptors and endozepine. Cholesterol is converted to pregnenolone by cytochrome P450scc (4), transported out of the mitochondria and is converted to progesterone by $3 \beta$-hydroxysteroid dehydrogenase, $\Delta^{5}, \Delta^{4}$ isomerase (3ß-HSD) (5) which is present in the smooth endoplasmic reticulum. Progesterone appears to diffuse from the luteal cell. ACAT: acyl coenzyme A:cholesterol acyltransferase.

(P450scc) and steroidogenic acute regulatory protein (StAR; Juengel et al., 1995a,b). Exogenous growth hormone $(\mathrm{GH})$ also increases concentrations of progesterone in serum (Schemm et al., 1990) and GH is necessary for normal luteal development in ewes (Juengel et al., 1995a).

Prostaglandin $\mathrm{F}_{2 \alpha}$ causes a marked decrease in secretion of progesterone from the ovine corpus luteum in vivo and from large luteal cells in vitro, which appears to be mediated via the effects of the PKC system (Wiltbank et al., 1989a; Tandeski et al., 1996). Treatment with $\mathrm{PGF}_{2 \alpha}$ also has long-term molecular effects including decreased luteal concentrations of mRNA encoding LH receptor (Guy et al., 1995), low density lipoprotein (LDL) receptor (Tandeski et al., 1996), StAR (Juengel et al., 1995b; Fiedler et al., 1999),

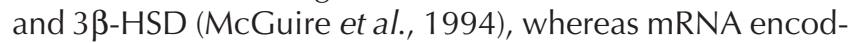
ing high density lipoprotein (HDL) receptor (Tandeski et al.,
1996) and P450scc (McGuire et al., 1994) are not altered markedly. Prostaglandin treatment also reduces ovarian and luteal blood flow (Niswender et al., 1975) and induces DNA fragmentation and apoptosis resulting in cell death, apparently as a result of increased intracellular free calcium (Wiltbank et al., 1989b). There is increasing evidence that some of the effects of $\mathrm{PGF}_{2 \alpha}$ on luteal tissue are mediated by endothelin 1 (Hinkley and Milvae, 2001).

\section{Acute regulation of the secretion of progesterone}

Both luteotrophic and luteolytic hormones appear to regulate secretion of progesterone acutely by affecting transport of cholesterol to the inner mitochondrial membrane and, in the long term, by regulating concentrations of mRNAs that encode important receptors, transport proteins 


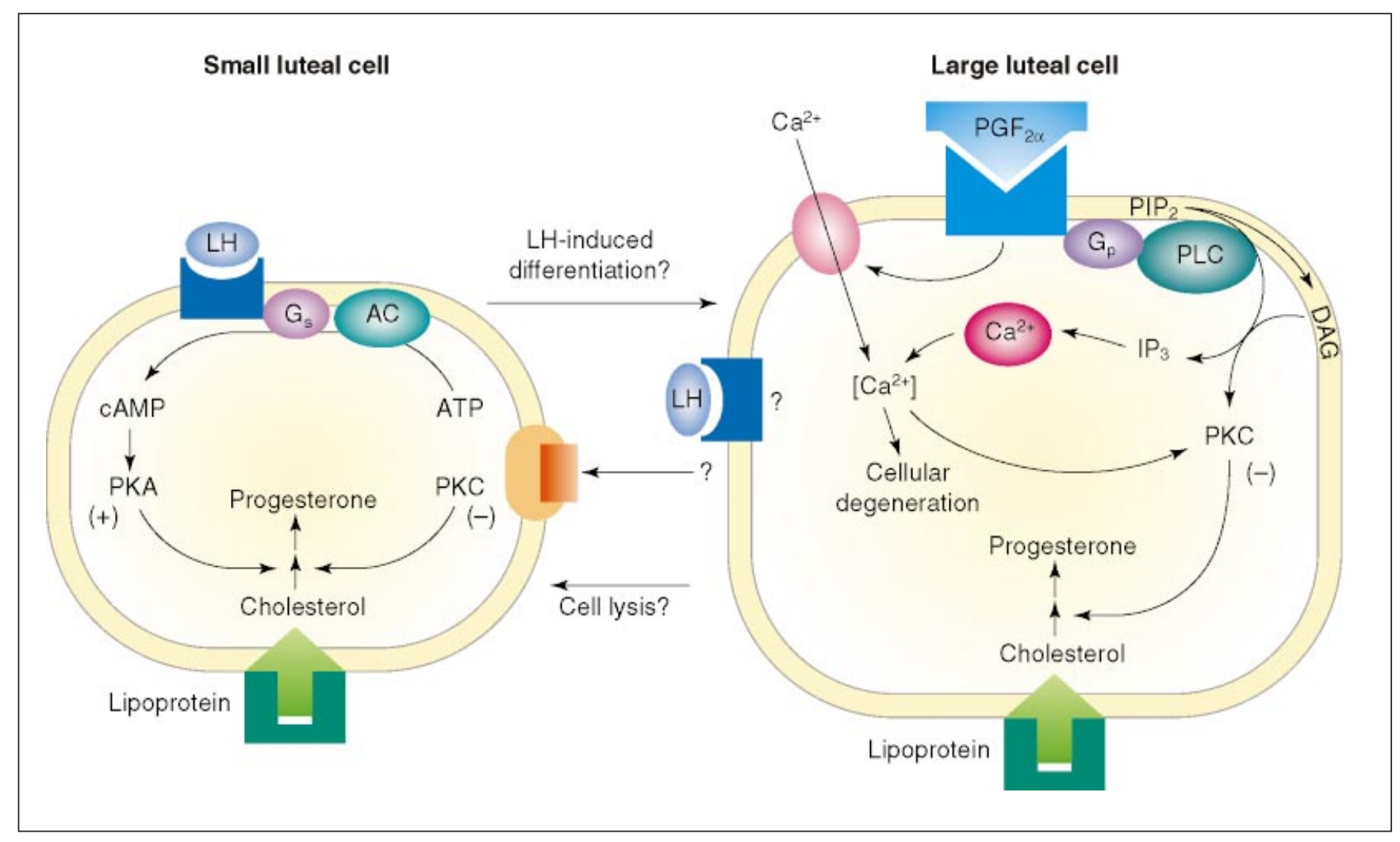

Fig. 2. Current working model for the second messenger pathways involved in regulating the small (left) and large (right) luteal cells. In small luteal cells, binding of LH to its receptor activates the protein kinase A (PKA) second messenger pathway, which stimulates synthesis of progesterone. Pharmacological activation of PKC inhibits progesterone synthesis in small luteal cells, although the factors that activate PKC have not been elucidated. In large cells, LH binding to its receptor does not increase intracellular concentrations of cAMP or increase synthesis of progesterone. Binding of $\mathrm{PGF}_{2 \alpha}$ to its receptor activates PKC, which is inhibitory to synthesis of progesterone and causes an influx of calcium leading to cellular degeneration. AC: adenylate cyclase; DAG: diacylglycerol; Gp: G protein causing stimulation of phospholipase C; Gs: G protein causing stimulation of adenylate cyclase; $\mathrm{IP}_{3}$ : inositol 1,4,5-trisphosphate; PIP ${ }_{2}$ : phosphatidylinositol 4,5-bisphosphate; PLC: phospholipase C.

and steroidogenic enzymes. However, the effects of luteotrophic and luteolytic stimuli are different in the two steroidogenic types of luteal cell.

As the rate-limiting step in the biosynthesis of progesterone is the transport of cholesterol to the inner mitochondrial membrane (Crivello and Jefcoate, 1980; Jefcoate et al., 1987; Wiltbank et al., 1993; Belfiore et al., 1994), which also appears to be the primary site of acute hormonal regulation (Grusenmeyer and Pate, 1992; Wiltbank et al., 1993; Belfiore et al., 1994), this process has been studied. At least three essential proteins have been identified that are involved in the transport of cholesterol from the outer to the inner mitochondrial membrane. These three proteins are StAR, peripheral type benzodiazepine receptor (PBR) and endozepine, the natural ligand for PBR. StAR is synthesized as a $37 \mathrm{kDa}$ protein that contains a mitochondrial targeting sequence (Stocco and Sodeman, 1991; Clark et al., 1994) and multiple potential PKA and PKC phosphorylation sites (J. L. Juengel and G. D. Niswender, unpublished). PKC phosphorylation sites are present in the mitochondrial targeting sequence that may be involved in reduced cholesterol transport and decreased steroidogenesis that occurs after activation of PKC. Messenger RNA encoding StAR is present in tissues in which mitochondrial steroid hydroxylations are acutely stimulated by PKA (Sugawara et al., 1995). Two proteins of similar size (one acidic, one basic, both $30 \mathrm{kDa}$ ), the synthesis of which is associated with increased steroid production after hormonal stimulation, have been identified (Krueger and Orme-Johnson, 1983; Pon and Orme-Johnson, 1986; Pon et al., 1986a; Stocco and Chaudhary, 1990; Stocco and Chen, 1991). Phosphorylation of these proteins is correlated with further increases in steroid secretion (Pon et al., 1986b; Epstein and Orme-Johnson, 1991). The proteins localized to mitochondria and were generated by post-translational modifications of a protein of $37 \mathrm{kDa}$, which was initially cleaved to a $32 \mathrm{kDa}$ form and converted rapidly to acidic and basic $30 \mathrm{kDa}$ forms during insertion into the mitochondrial 


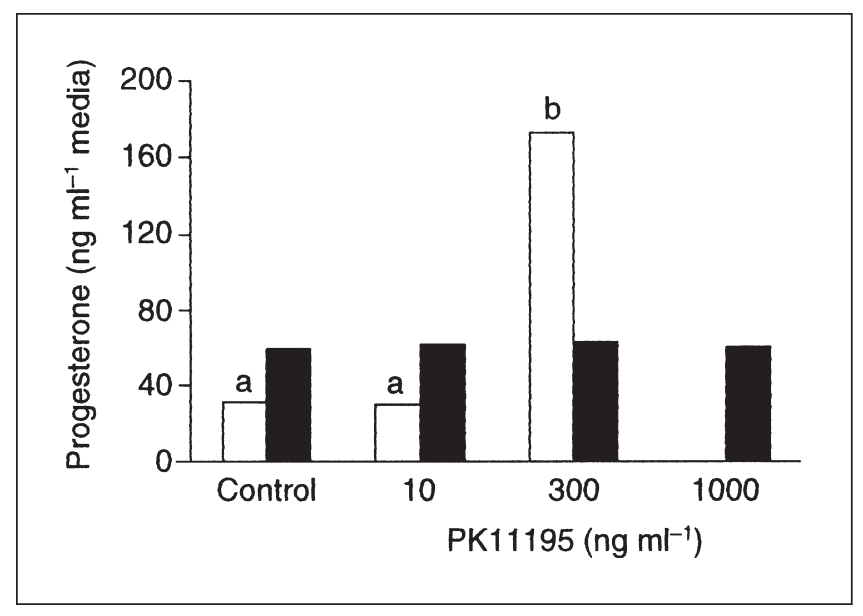

Fig. 3. Concentrations of progesterone in media after incubation of ( $\square$ ) small (250 000 per well) and (ם) large (50 000 per well) luteal cells with increasing concentrations of PK11195, a peripheral-type benzodiazepine receptor (PBR) agonist. Each mean represents triplicate dishes run in three separate experiments. Even at a concentration of $1 \mu \mathrm{g}$, PK11195 had no effect on secretion of progesterone from large luteal cells.

membrane. Waterman (1995) hypothesized that it was during insertion of the protein into the mitochondrial membrane that cholesterol was transported to cytochrome P450scc, a key component of the enzyme complex that cleaves the side chain from cholesterol to form pregnenolone. The fact that mutated forms of StAR in which the mitochondrial targeting sequence has been deleted retain some ability to stimulate steroidogenesis makes this hypothesis questionable (Arakane et al., 1996). However, the critical role played by StAR in steroidogenesis was clearly documented by Lin et al. (1995) who demonstrated that the severely reduced adrenal and gonadal steroid synthesis in patients with congenital lipoid adrenal hyperplasia was the result of mutations in the StAR gene. An increase in StAR transcription after trophic hormone stimulation and increased intracellular CAMP has been demonstrated in several species (Sugawara et al., 1995; Caron et al., 1997; Sandhoff et al., 1998). However, there is no consensus CAMP response element in the StAR promoter. For an excellent review of the actions and properties of StAR, see Stocco (2001).

Peripheral-type benzodiazepine receptors (PBR) also appear to play a role in cholesterol transport from the outer to the inner mitochondrial membrane. Targeted deletion of the receptor from the constitutively steroid-secreting Leydig tumour cell line (R2C cells) reduced steroid secretion markedly, whereas reintroduction of the receptor reestablished increased steroid secretion (Papadopoulos et al., 1997). Phosphorylation of PBR by PKA enhances cholesterol transport (Papadopoulos et al., 1997) and models indicate that this receptor may serve as a cholesterol channel.
Mutations in the receptor at $\mathrm{Y} 153$ and $\mathrm{R} 156$ result in reduced interactions between PBR and cholesterol ( $\mathrm{Li}$ and Papadopoulos, 1998). The number of PBR receptors in steroidogenic cells does not appear to be hormonally regulated (Papadopoulos and Brown, 1995) although a marked increase in the affinity of the receptor has been reported after trophic hormone stimulation of steroidogenic cells (Papadopoulos and Brown, 1995).

The natural ligand for PBR, endozepine, also appears to be critical for regulating cholesterol transport as targeted deletion of this molecule inhibits both trophic hormone stimulation (MA-10 Leydig tumour cells) and reduces basal amounts (R2C cells) of steroidogenesis (Boujrad et al., 1993). Thus, there is compelling evidence that at least three proteins play a role in regulating the transport of cholesterol across mitochondrial membranes. The fact that transport of cholesterol across mitochondrial membranes appears to be the rate-limiting step in steroidogenesis and that it is this step that is most markedly influenced by second messenger pathways provides the rationale for focusing research on this process.

One of the most intriguing questions remaining to be answered is: what is responsible for the large amount of unstimulated secretion of progesterone from large luteal cells compared with small steroidogenic luteal cells? This question is important because this type of cell secretes $>85 \%$ of the progesterone produced by the corpus luteum (Niswender et al., 1985). Progesterone secretion from large luteal cells may be constituitive, as factors that acutely stimulate the secretion of progesterone from these cells have a rather modest (usually less than a doubling) effect compared with the 5-15-fold increase noted with small luteal cells. As the transport of cholesterol from the cytosol to the inner mitochondrial membrane appears to be the key process in the acute regulation of secretion of progesterone, it seems likely that differences in the control of progesterone secretion from the two types of luteal cell involve differences in the functions of the three proteins known to be involved in this process.

This possibility was investigated by incubating purified large (35 000 per well) and small (250000 per well) luteal cells (Fitz et al., 1982) with increasing doses of PK11195, a PBR receptor agonist, and measuring the secretion of progesterone. The experiment was performed with triplicate wells per treatment and replicated three times with cells obtained from different ewes. There was an approximately sixfold increase $(P<0.01)$ in the secretion of progesterone from small luteal cells incubated in 300 ng PK11195 ml-1 compared with saline-treated control cells (Fig. 3). Small luteal cells were not treated with $1000 \mathrm{ng} \mathrm{ml} \mathrm{m}^{-1}$ owing to the large number required for each dose. There was no increase in the secretion of progesterone from large luteal cells when incubated with PK11195 at concentrations ranging from 10 to $1000 \mathrm{ng} \mathrm{ml}^{-1}$. These data were interpreted as an indication that endozepine plays an important role in regulating the secretion of progesterone from small luteal cells, but the lack of effect on large luteal cells was surprising. The 
Table 1. Relative amounts of steroidogenic acute regulatory protein (StAR) and endozepine protein in small versus large luteal cells

\begin{tabular}{lcc}
\hline & Small luteal cells & Large luteal cells \\
\hline StAR & $18875 \pm 3618^{*}$ & $25454 \pm 4711$ \\
Endozepine & $7214 \pm 1180^{\mathrm{a}}$ & $24829 \pm 2586^{\mathrm{b}}$ \\
\hline
\end{tabular}

*Relative densitometric units per microgram of protein after western analysis. Quantitation was performed on the $30 \mathrm{kDa}$ band for StAR, as the $37 \mathrm{kDa}$ band appeared to be $<5 \%$ of the total (five of eight samples) or undetectable (one of four small luteal cell samples and two of four large luteal cell samples).

$\mathrm{a}, \mathrm{b} P<0.01$.

relative concentrations of endozepine and StAR protein in purified preparations of the two steroidogenic types of cell were determined by western blot analysis to investigate whether the high basal secretion of progesterone from large luteal cells is due to high endogenous endozepine concentrations. Protein preparations were obtained from four purified preparations of small $\left(53-85 \times 10^{6}\right.$ cells $)$ and large (3.0-6.8 $\times 10^{6}$ cells) steroidogenic luteal cells. The StAR antibody was produced in a rabbit against a 15 amino acid sequence (residues 120-134) of ovine StAR. The antiserum used for endozepine was kindly provided by $\mathrm{V}$. Papadopoulos (Georgetown University). As large luteal cells are approximately seven times larger in volume than small luteal cells, the data were expressed per $\mu \mathrm{g}$ of protein. There were no differences in the relative concentrations of StAR in the two types of cell (Table 1). However, there was an approximately 3.5-fold higher concentration of endozepine in large versus small luteal cells. These data are compatible with the suggestion that increased endozepine concentrations in large luteal cells plays a role in the increased basal concentrations of progesterone secreted from this type of cell.

Our current model for how these proteins might interact in the transport of cholesterol is shown (Fig. 4). A key component of this model is that StAR is a cytosolic cholesterol transport molecule targeted to the mitochondrial membrane, with which it interacts in an unidentified way to provide cholesterol to PBR, which functions to transport cholesterol to the inner mitochondrial membrane. The functioning of StAR as a sterol transfer protein (Kallen et al., 1998) and the cholesterol binding properties of PBR (Li and Papadopoulos, 1998) are well documented. As an initial test of this model, intrinsically fluorescent forms of StAR and PBR have been constructed and laser-optical methods based on fluorescent resonance energy transfer (FRET) have been used to demonstrate that StAR and PBR interact in the mitochondrial membrane. Fusion proteins were produced that contained green fluorescent protein (GFP, donor fluorophore) and yellow fluorescent protein (YFP, acceptor fluorophore) fused to the $C$ terminus of ovine StAR and ovine PBR, respectively. These intrinsically fluorescent proteins were stably transfected into Cos-7 cells. The fluorescent proteins were shown to be biologically active on the basis of the increased production of preg-

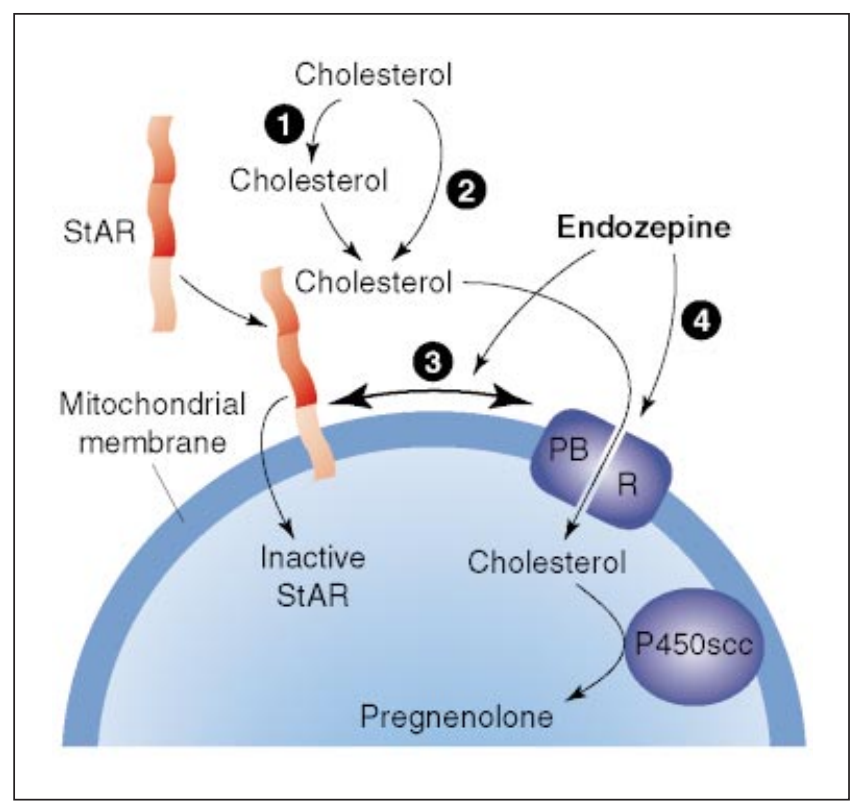

Fig. 4. Hypothetical model for cholesterol transport into mitochondria of steroidogenic cells. Steroidogenic acute regulatory protein (StAR) may bind cholesterol in the cytoplasm (1) or after it has been targeted to the mitochondria (2). StAR transfers cholesterol to peripheral-type benzodiazepine receptors (PBR) (3) where cholesterol is transported across the outer to the inner mitochondrial membrane. Endozepine may change the conformation of PBR enabling it to transport the cholesterol (4) or facilitate the StAR to PBR interaction or exchange of cholesterol (3).

nenolone (StAR) or enhanced binding of 3H-PK1195 to PBR receptor under appropriate conditions (West et al., 2001). If significant energy transfer occurs, the fluorescent molecules are less than $100 \mathrm{~A}^{\circ}$ from each other. Fluorescence energy transfer efficiency between StAR-GFP and PBR-YFP was $22.0+0.9 \%$ (West et al., 2001), a 4.9-fold increase above non-specific energy transfer between GFP alone and PBR-YFP $(P<0.0001)$. Thus, it appears that StAR and PBR are associated closely in the mitochondrial membrane, confirming that the proposed model for cholesterol transport is correct, at least in part.

Additional experiments are underway to address the effects of activation of PKA and PKC second messenger pathways on StAR-PBR interactions. PKA activation probably enhances the interaction of StAR and PBR, whereas PKC activation reduces this interaction, on the basis of the known effects of these second messenger pathways on the synthesis of progesterone. It is difficult to predict whether the two steroidogenic types of luteal cell will respond differently. The role played by endozepine also needs further investigation. This ligand may have a direct effect on modifying the activity of PBR or may enhance StAR-PBR interactions. Obtaining this information is fundamental to understanding the molecular regulation of the secretion of progesterone. 


\section{References}

Key references are identified by asterisks.

Arakane F, Sugawara T, Nishino H, Liu Z, Holt JA, Pain D, Stocco DM, Miller WL and Strauss JF, III (1996) Steroidogenic acute regulatory protein (StAR) retains activity in the absence of its mitochondrial import sequence. Implications for the mechanism of StAR action Proceedings of the National Academy of Sciences USA 93 13 731-13 736

Belfiore CJ, Hawkins DE, Wiltbank MC and Niswender GD (1994) Regulation of cytochrome $P 450_{\text {scc }}$ synthesis and activity in the ovine corpus luteum Journal of Steroid Biochemistry and Molecular Biology $51283-290$

Boujrad N, Hudson JR, Jr and Papadopoulos V (1993) Inhibition of hormone-stimulated steroidogenesis in cultured Leydig tumor cells by a cholesterol-linked phosphorothioate oligodeoxynucleotide antisense to diazepam-binding inhibitor Proceedings of the National Academy of Sciences USA 90 5728-5731

Caron KM, Soo Sc, Wetsel WC, Stocco DM, Clark BJ and Parker KL (1997) Targeted disruption of the mouse gene encoding steroidogenic acute regulatory protein provides insights into congenital lipoid adrenal hyperplasia Proceedings of the National Academy of Sciences USA 94 $11540-11545$

Clark BJ, Wells J, King SR and Stocco DM (1994) The purification, cloning, and expression of a novel luteinizing hormone-induced mitochondrial protein in MA-10 mouse Leydig tumor cells. Characterization of the steroidogenic acute regulatory protein (StAR) Journal of Biological Chemistry $26929314-29322$

Crivello JF and Jefcoate CR (1980) Intracellular movement of cholesterol in rat adrenal cells. Kinetics and effects of inhibitors Journal of Biological Chemistry 255 8144-8151

Denamur R, Martinet J and Short RV (1973) Pituitary control of the ovine corpus luteum Journal of Reproduction and Fertility 32 207-220

Epstein LR and Orme-Johnson NR (1991) Regulation of steroid hormone biosynthesis. Identification of precursors of a phosphoprotein targeted to the mitochondrion in stimulated rat adrenal cortex cells Journal of Biological Chemistry 26619 739-19 745

Fiedler EP, Flouffe L, Jr, Hales DB, Hales KH and Khan I (1999) Prostaglandin $\mathrm{F}$ (2alpha) induces a rapid decline in progesterone production and steroidogenic acute regulatory protein expression in isolated rat corpus luteum without altering messenger ribonucleic acid expression Biology of Reproduction 61 643-650

Fitz TA, Mayan MH, Sawyer HR and Niswender GD (1982) Characterization of two steroidogenic cell types in the ovine corpus luteum Biology of Reproduction 27 703-711

Grusenmeyer DP and Pate JL (1992) Localization of prostaglandins $F_{2 \alpha}$ inhibition of lipoprotein use by bovine luteal cells Journal of Reproduction and Fertility 94 311-318

Guy MK, Juengel JL, Tandeski TR and Niswender GD (1995) Steady-state concentrations of mRNA encoding the receptor for luteinizing hormone during the estrous cycle and following prostaglandin $\mathrm{F}_{2 \alpha}$ treatment of ewes Endocrine 3 585-589

Hansel W, Concannon PW and Lukaszewska JH (1973) Corpora lutea of the large domestic animals Biology of Reproduction 8 222-245

Hinckley ST and Milvae RA (2001) Endothelin-1 mediates prostaglandin $\mathrm{F}_{2 \alpha}$-induced luteal regression in the ewe Biology of Reproduction $\mathbf{6 4}$ 1619-1623

Jefcoate CR, DiBartolomeis MJ, Williams CA and McNamara BC (1987) ACTH regulation of cholesterol movement in isolated adrenal cells Journal of Steroid Biochemistry 27 721-729

Jefcoate CR, McNamara BC, Artemenko I and Yamazaki T (1992) Regulation of cholesterol movement to mitochondrial cytochrome $P 450_{\text {scc }}$ in steroid hormone synthesis Journal of Steroid Biochemistry and Molecular Biology 43 751-767

Juengel JL, Nett TM, Tandeski TR, Eckery DC, Sawyer HR and Niswender GD (1995a) Effect of luteinizing hormone and growth hormone on luteal development in hypophysectomized ewes Endocrine 3 323-326

*Juengel JL, Meberg BM, Turzillo AM, Nett TM and Niswender GD (1995b) Hormone regulation of mRNA encoding steroidogenic acute regulatory protein in ovine corpora lutea Endocrinology 136 5423-5429
Kallen CB, Billheimer JT, Summers SA, Staybrook SE, Lewis M and Strauss JF, III (1998) Steroidogenic acute regulatory protein (StAR) is a sterol transfer protein Journal of Biological Chemistry 27326 285-26 288

Kaltenbach CC, Graber JW, Niswender GD and Nalbandov AV (1968) Luteotrophic properties of some pituitary hormones in nonpregnant or pregnant hypophysectomized ewes Endocrinology 82 818-824

Krueger RJ and Orme-Johnson NR (1983) Acute adrenal hormone stimulation of adrenal corticosteroidogenesis. Discovery of a rapidly induced protein Journal of Biological Chemistry 25710 159-10 167

Li H and Papadopoulos V (1998) Peripheral type benzodiazepine receptor function in cholesterol transport. Identification of a putative cholesterol recognition/interaction amino acid sequence and consensus pattern Endocrinology 139 4991-4997

Lin D, Sugawara T, Strauss JF, III, Clark BJ, Stocco DM, Saenger P, Rogol A and Miller WL (1995) Role of steroidogenic acute regulatory protein in adrenal and gonadal steroidogenesis Science 267 1828-1831

McGuire WJ, Juengel JL and Niswender GD (1994) Protein kinase C second messenger system mediates the antisteroidogenic effects of prostaglandin $\mathrm{F}_{2 \alpha}$ in the ovine corpus luteum in vivo. Biology of Reproduction 51 800-806

Niswender GD and Nett TM (1994) Corpus luteum and its control in infraprimate species. In The Physiology of Reproduction Vol. 1 pp 781-816 Eds E Knobil and JD Neill. Raven Press, New York,

Niswender GD, Moore RT, Akbar AM, Nett TM and Diekman MA (1975) Flow of blood to the ovaries of ewes throughout the estrous cycle Biology of Reproduction 13 381-388

*Niswender GD, Schwall RH, Fitz TA, Farin C and Sawyer HR (1985) Regulation of luteal function in domestic ruminants: new concepts. In Recent Progress in Hormone Research Vol. 4 pp 101-142 Ed. RO Greep. Academic Press, New York

Niswender GD, Juengel JL, McGuire WJ, Belfiore CJ and Wiltbank MC (1994) Luteal function: the estrous cycle and early pregnancy Biology of Reproduction 50 239-247

*Papadopoulos V and Brown AS (1995) Role of the peripheral-type benzodiazepine receptor and the polypeptide diazepam binding inhibitor in steroidogenesis Journal of Steroid Biochemistry and Molecular Biology $53103-110$

Papadopoulos V, Amri H, Boujrad N et al. (1997) Peripheral benzodiazepine receptor in cholesterol transport and steroidogenesis Steroids 62 21-28

*Pon LA and Orme-Johnson NR (1986) Acute stimulation of steroidogenesis in corpus luteum and adrenal cortex by peptide hormones. Rapid induction of a similar protein in both tissues Journal of Biological Chemistry 261 6594-6599

Pon LA, Epstein LF and Orme-Johnson NR (1986a) Acute cAMP stimulation in Leydig cells: rapid accumulation of a protein similar to that detected in adrenal cortex and corpus luteum Endocrine Reviews 12 429-446

Pon LA, Hartigan JA and Orme-Johnson NR (1986b) Acute ACTH regulation of adrenal corticosteroid biosynthesis. Rapid accumulation of a phosphoprotein Journal of Biological Chemistry 26113 309-13 316

Sandhoff TW, Hales DB, Hales KH and McLean MP (1998) Transcriptional regulation of the rat steroidogenic acute regulatory protein gene by steroidogenic factor 1 Endocrinology 139 4820-4831

Schemm SR, Deaver DR, Griel LC and Muller LD (1990) Effects of recombinant bovine somatotropin on luteinizing hormone and ovarian function in lactating dairy cows Biology of Reproduction 42 815-82

Sridaran R, Philip GH, Li H, Culty M, Liu Z, Stocco DM and Papadopoulos V (1999) GnRH agonist treatment decreases progesterone synthesis, luteal peripheral benzodiazepine receptor mRNA, ligand binding and steroidogenic acute regulatory protein expression during pregnancy Journal of Molecular Endocrinology 22 45-54

*Stocco DM (2001) StAR protein and the regulation of steroid hormone biosynthesis Annual Reviews of Physiology 63 193-213

Stocco DM and Chaudhary LR (1990) Evidence for the functional coupling of cAMP in MA-10 mouse Leydig tumor cells Cell Signal 2 161-170

Stocco DM and Chen W (1991) Presence of identical mitochondrial proteins in unstimulated constitutive steroid-producing $\mathrm{R} 2 \mathrm{C}$ rat Leydig tumor and stimulated nonconstitutive steroid-producing MA-10 mouse Leydig tumor cells Endocrinology 128 1918-1926 
Stocco DM and Sodeman TC (1991) The 30 kDa mitochondrial proteins induced by hormone stimulation in Ma-10 mouse Leydig tumor cells are processed from larger precursors Journal of Biological Chemistry 266 19731-19738

Sugawara T, Holt JA, Driscoll D et al. (1995) Human steroidogenic acute regulatory protein: functional activity in COS-1 cells, tissue-specific expression, and mapping of the structural gene to $8 \mathrm{p} 112$ and a pseudogene to chromosome 13 Proceedings of the National Academy of Sciences USA 92 4478-4482

Tandeski TR, Juengel JL, Nett TM and Niswender GD (1996) Regulation of messenger RNA encoding low density lipoprotein receptor and high density lipoprotein binding protein in ovine corpora lutea Reproduction, Fertility and Development 8 1106-1114

Waterman MR (1995) A rising StAR: an essential role in cholesterol transport Science 267 1780-1781

West LA, Horvat RD, Roess DA, Barisas BG, Juengel JL and Niswender GD (2001) Steroidogenic acute regulatory protein and peripheral-type benzodiazepine receptor associate at the mitochondrial membrane Endocrinology $\mathbf{1 4 2} 502-505$

Wiltbank MC, Knickerbocker JJ and Niswender GD (1989a) Regulation of the corpus luteum by protein kinase C I. Phosphorylation activity and steroidogenic action in large and small luteal cells Biology of Reproduction 40 1194-1200

Wiltbank MC, Guthrie PB, Mattson MP, Kater SB and Niswender GD (1989b) Hormonal regulation of free intracellular calcium concentrations in small and large ovine luteal cells Biology of Reproduction $\mathbf{4 1}$ 771-778

Wiltbank MC, Diskin MG and Niswender GD (1991) Differential actions of second messenger systems in the corpus luteum Journal of Reproduction and Fertility Supplement $\mathbf{4 3}$ 65-75

Wiltbank MC, Belfiore CJ and Niswender GD (1993) Steroidogenic enzyme activity after acute activation of protein kinase (PK) A and PKC in ovine small and large luteal cells Molecular and Cellular Endocrinology 97 $1-7$ 